\title{
Peningkatan Kemampuan Berfikir Kritis Peserta Didik pada Muatan Matematika Melalui Model Pembelajaran Problem Solving di Kelas VI SDN 146/X Tanjung Solok pada Semester Ganjil Tahun Ajaran 2021/2022
}

\author{
Toni \\ SDN 146/X Tanjung Solok \\ J1. Maju Jaya, RT.11 Kelurahan Tanjung Solok, Tanjung Solok, Kec. Kuala Jambi, Kab. Tanjung Jabung Timur, Jambi \\ tony8129@gmail.com
}

\begin{abstract}
This research is motivated by the students' thinking ability in learning mathematics is still lacking. The purpose of this study was to obtain information and discuss about improving students' critical thinking skills on mathematics content through problem solving learning models in class VI SDN 146/X Tanjung Solok in the odd semester of the 2021/2022 school year. This type of research is classroom action research (CAR) by following four stages, namely planning, implementation, observation, and reflection. This research was conducted at SDN 146/X Tanjung Solok in the odd semester of the 2021/2022 academic year with the subject of class VI students totaling 17 students. This study consisted of two cycles, where each cycle consisted of two meetings. Data collection techniques used observation sheets, tests, field notes, and documentation. Data were analyzed using percentages and data reduction on students' critical thinking skills. Based on the results of research and discussion, it can be concluded that through problem solving learning models can improve students' critical thinking skills in learning mathematics in class VI SDN 146/X Tanjung Solok. This can be seen from the percentage of students' learning completeness from the first cycle $(41 \%)$ and increased in the second cycle $(82 \%)$.
\end{abstract}

Keywords: Critical Thinking Ability, Mathematics, Problem Solving

\begin{abstract}
Abstrak
Penelitian ini dilatarbelakangi oleh kemampuan berfikir peserta didik dalam pembelajaran matematika masih kurang. Tujuan dari penelitian ini adalah untuk mendapatkan informasi dan membahas tentang peningkatan kemampuan berfikir kritis peserta didik pada muatan matematika melalui model pembelajaran problem solving di kelas vi SDN 146/X Tanjung Solok pada semester ganjil tahun ajaran 2021/2022. Jenis penelitian ini adalah penelitian tindakan kelas (PTK) dengan mengikuti empat tahapan yaitu perencanaan, pelaksanaan, observasi, dan refleksi. Penelitian ini dilaksanakan di SDN 146/X Tanjung Solok pada semester ganjil tahun ajaran 2021/2022 dengan subjek peserta didik kelas VI yang berjumlah sebanyak 17 orang peserta didik. Penelitian ini terdiri dari dua siklus, dimana masing-masing siklus terdiri dari dua kali pertemuan. Teknik pengumpulan data menggunakan lembar observasi, tes, catatan lapangan, dan dokumentasi. Data dianalisis dengan menggunakan persentase dan reduksi data terhadap kemampuan berfikir kritis siswa. Berdasarkan hasil penelitian dan pembahasan dapat disimpulkan bahwa melalui model pembelajaran problem solving dapat meningkatkan kemampuan berfikir kritis peserta didik dalam pembelajaran matematika di kelas VI SDN 146/X Tanjung Solok. Hal ini dapat dilihat dari persentase ketuntasan belajar peserta didik dari siklus I (41\%) dan meningkat pada siklus II $(82 \%)$.
\end{abstract}

Kata Kunci: Kemampuan Berfikir Kritis, Matematika, Problem Solving

Copyright (c) 2022 Tony

Corresponding author: Tony

Email Address: tony8129@gmail.com (J1. Maju Jaya, RT.11 Tanjung Solok,. Tanjung Jabung Timur, Jambi)

Received 10 January 2022, Accepted 20 January 2022, Published 28 January 2022

\section{PENDAHULUAN}

Perkembangan ilmu pengetahuan dan teknologi memungkinkan semua pihak dapat memperoleh informasi dengan melimpah, cepat dan mudah dari berbagai sumber dan tempat di dunia. Tujuan pembelajaran matematika menurut Kurikulum 2013 (Kemendikbud, 2013) menekankan pada dimensi pedagogik modern dalam pembelajaran, yaitu menggunakan pendekatan scientific (ilmiah). 
Dalam pembelajaran matematika kegiatan yang dilakukan agar pembelajaran bermakna yaitu mengamati, menanya, mencoba, menalar, menyaji, dan mencipta. Semua kemampuan yang telah dinyatakan di atas, diharapkan dapat dimiliki oleh siswa. Namun tidak dapat terwujud apabila hanya mengandalkan proses pembelajaran yang selama ini terbiasa ada di sekolah kita, seperti mengajarkan dengan diajari teori/definisi/teorema, kemudian diberikan contoh-contoh dan terakhir diberikan latihan soal (Soedjadi, 2000). Proses belajar seperti ini tidak membuat anak didik berkembang dan memiliki bernalar berdasarkan pemikirannya, tapi justru lebih menerima ilmu secara pasif. Dengan demikian, langkah-langkah dan proses pembelajaran yang selama ini umumnya dilakukan oleh para guru di sekolah adalah kurang tepat, karena justru akan membuat anak didik menjadi pribadi yang pasif.

Berdasarkan observasi dilakukan di kelas VI SDN 146/X Tanjung Solok dalam pembelajaran matematika, peserta didik mempunyai kemampuan berfikir kritis yang masih rendah. Dari rerata hasil ulangan harian yang didapatkan, terlihat bahwa prosentase peserta didik di bawah kriteria ketuntasan minimum (60), rata-rata hasil belajar peserta didik pada saat diobservasi sebesaar 45,5. Beberapa aspek diyakini menjadi penyebab rendahnya kemampuan penalaran tersebut. Peneliti mendapatkan bahwa peserta didik hanya terbiasa mengerjakan soal-soal yang menggunakan rumus-rumus dan prosedur baku yang sudah ada. Kalau contoh soal yang diberikan bervariasi dan berbeda dari contoh soal atau penggunaan rumus-rumus dan prosedur baku, maka peserta didik mengalami kesulitan dan tidak mampu menyelesaikannya. Pemahaman peserta didik terhadap konsep matematika masih kurang dan peserta didik cenderung menghafal rumus semata. Sebagian besar peserta didik tidak memahami langkah-langkah dalam menyelesaikan soal, karena guru cenderung memberitahu konsep dan rumusrumus serta cara penggunaannya. Pembelajaran masih amat tergantung oleh kehadiran, peran dan penjelasan guru atas materi pelajaran. Dari paparan ini, dapat dipahami bahwa kemampuan peserta didik dalam penalaran menjadi persoalan yang perlu diatasi sesegera mungkin.

Melihat kenyataan tersebut di atas maka proses pembelajaran belum dapat dikatakan baik atau masih kurang usaha untuk meningkatkannya. Proses pembelajaran yang baik tersebut harus dapat memberikan kesan dan bermakna bagi peserta didik serta pembelajaran tersebut menyenangkan bagi peserta didik sesuai kebutuhan perkembangannya, untuk itu diperlukan suatu model pembelajaran yang dapat meningkatkan kemampuan peserta didik dalam pembelajaran matematika.

Beberapa pendekatan dan model pembelajaran telah dikembangkan oleh para peneliti dan praktisi pendidikan untuk meningkatkan kemampuan penalaran dan kemampuan berpikir tingkat tinggi lainnya. Mujis \& Reynolds (2008:186) mengungkapkan empat pendekatan untuk meningkatkan keterampilan berpikir, yaitu pendekatan problem solving, metakognitif, open-ended dan aktif, serta pendekatan berpikir formal. Sementara itu, Rusman (2010: 141-142) mengelompokkan beberapa model pembelajaran seperti berpikir induktif, inkuiri ilmiah, penemuan konsep, dan pertumbuhan kognitif dalam rumpun model pemprosesan informasi. Rumpun model ini secara umum berbasis pada 
teori kognitif Piaget dengan orientasi membangun kemampuan peserta didik dalammengumpulkan dan mengolah informasi, memecahkan masalah dan menemukan konsep.

Model Problem Solving merupakan model yang dapat mengembangkan keterampilan berpikir peserta didik dan melatih kemampuan dalam menghadapi dan menyelesaikan masalah. Menurut Wina (2008:214) "Model problem solving merupakan rangkaian aktivitas pembelajaran yang menekankan pada proses penyelesaian masalah secara ilmiah, mulai dari mencari data sampai pada penarikan kesimpulan".

Berdasarkan latar belakang yang dijelaskan di atas, peneliti tertarik untuk memperbaiki proses pembelajaran dengan melakukan penelitian tindakan kelas yang bertujuan untuk mendeskripsikan dan mendapatkan informasi tentang peningkatan kemampuan berfikir kritis peserta didik pada muatan matematika melalui model pembelajaran problem solving di kelas VI SDN 146/X Tanjung Solok pada semester ganji tahun ajaran 2021/2022.

Kemampuan berfikir kritis merupakan kemampuan yang sangat penting. Hal ini seperti yang diungkapkan oleh Susanto (2013:121) "Kemampuan berfikir kritis merupakan kemampuan atau cara berfikir tentang ide atau gagasan yang berhubungan dengan konsep yang diberikaan. Menurut Gunawan (2003:177-178), menyatakan bahwa keterampilan berpikir kritis adalah kemampuan untuk berpikir pada level yang kompleks dan menggunakan proses analisis dan evaluasi. Jadi seseorang yang berpikir kritis akan selalu aktif dalam memahami dan menganalisis semua informasi yang didapatkan.

Jadi dapat disimpulkan bahwa kemampuan berpikir kritis merupakan kemampuan yang sangat penting bagi setiap orang yang digunakan untuk memcahkan masalah kehidupan dengan berpikir serius, aktif, teliti dalam menganalisa semua informasi yang mereka terima dengan menyertakan alasan yang rasional sehingga setiap tindakan yang akan dilakukan adalah benar.

Menurut Susanto (2013:123) ciri-ciri orang yang berfikir kritis adalah orang-orang yang memiliki kemampuan : (a) Orang yang tidak begitu saja menerima atau menolak sesuatu, (b) Mencermati, menganalisis dan mengevaluasi informasi sebelum menentukan apakah mereka menerima atau tidak, (c) Menangguhkan keputusan jika belum memiliki pemahaman tenatang suatu informasi (d) Mempunyai keinginan untuk bernalar, keinginan untuk ditantang dan hasrat untuk mencari kebenaran.

Berkaitan dengan istilah berpikir, menurut Vincent Ruggiero dalam Yulnaida (2015:16) berpikir adalah sebagai seluruh aktivitas mental yang membantu dalam merumuskan atau memecahkan, memuat keputusan, atau memenuhi keinginan untuk memahami. Sudiarta (2007:27) dalam Yulnaida (2015:16) mengungkapkan bahwa "kemampuan berpikir kritis melibatkan kemampuan untuk membuat alasan yang masuk akal dalam situasi yang kompleks.” Berpikir kritis merupakan proses terorganisasi yang melibatkan aktivitas mental seperti dalam memecahkan masalah, pembuatan keputusan dan analisis asumsi. 
Matematika merupakan ide-ide abstrak yang berisi simbol-simbol (Susanto, 2013: 183). Suriasumantri (2005:190) menyatakan, "matematika adalah bahasa yang melambangkan serangkaian makna dari pernyataan yang ingin kita sampaikan. Hudojo (1998) matematika merupakan ide-ide abstrak yang diberi simbol-simbol itu tersusun secara hirarkis dan penalarannya deduktif, sehingga belajar matematika itu merupakan kegiatan mental yang tinggi.

Dari beberapa pengertian mengenai matematika di atas, dapat disimpulkan bahwa matematika merupakan kumpulan dari beberapa ide-ide abstrak dan simbol-simbol. Ide dan simbol tersebut disusun secara hirarkis dan penalaran yang deduktif, sehingga untuk mempelajarinya dibutuhkan mental yang tinggi. Matematika merupakan salah satu bidang studi yang ada pada semua jenjang pendidikan, mulai dari tingkat sekolah dasar hingga perguruan tinggi (Susanto, 2013: 183).

Berdasarkan beberapa pendapat di atas dapat disimpulkan bahwa matematika adalah ilmu tentang bahasa simbol, bahasa numerik, metode berfikir logis, sains yang memanipulasi simbol, ilmu tentang bilangan dan ruang, serta ilmu yang mempelajari hubungan pola, urutan, bentuk dan struktur terorganisasi yang dalam pembuktian kebenarannya melalui proses temuan sendiri.

Berhasil atau tidaknya suatu proses pembelajaran dipengaruhi oleh pemilihan dan penggunaan model yang tepat dalam pembelajaran. Menurut Depdiknas (dalam Alben, 2006:69) model merupakan suatu rangkaian tindakan yang terpola atau terorganisir, berdasarkan prinsip-prinsip tertentu seperti: dasar filosofis, prinsip psikologis, prinsip didaktis yang terarah secara sistimatis pada tujuan-tujuan yang hendak dicapai. Selanjutnya Muhibbin (2007:139) menjelaskan model merupakan segala cara yang digunakan dalam menunjang efektifitas dan efisiensi proses pembelajaran. Jadi model adalah serangkaian cara yang digunakan berdasarkan prinsip-prinsip tertentu dalam menunjang efektifitasnya suatu pembelajaran.

Menurut Nuryani (2005:92) "Model lebih menekankan pada strategi dalam perencanaan yang lebih mengutamakan bagaimana cara-cara yang kita lakukan dalam melaksanakan sesuatu kegaiatan, salah satu contohnya adalah dalam proses pembelajaran. Menurut Anna (2005:75) "Pembelajaran merupakan proses interaksi yang dilakukan oleh guru dan siswa, baik di dalam maupun di luar kelas dengan menggunakan berbagai sumber". Pembelajaran merupakan kegiatan yang dilakukan untuk memfasilitasi, dan meningkatkan intensitas dan kualitas belajar pada diri siswa". Berdasarkan pendapat di atas dapat disimpulkan pembelajaran merupakan proses hubungan timbal balik antara guru dan peserta didik dengan menggunakan berbagai sumber belajar untuk meningkatkan kualitas belajar siswa.

Problem solving merupakan salah satu model yang dapat digunakan dalam proses pembelajaran.. Menurut Nasution (2003:170) “Problem solving dapat dipandang sebagai proses di mana peserta didik menemukan kombinasi aturan-aturan yang telah dipelajarinya sebelumnya dan digunakan untuk memecahkan masalah yang baru".Sedangkan menurut Abin (2007:229) "Dalam problem solving peserta didik belajar merumuskan dan memecahkan masalah atau memberikan respon terhadap ransangan yang menggambarkan, membangkitkann situasi masalah dengan 
menggunakan berbagai aturan yang telah dikuasainya". Berdasarkan pendapat di atas problem solving adalah suatu proses yang kompleks dalam penyelesaian terhadap suatu masalah mulai dari menyadari adanya masalah, merumuskan masalah, memberikan respon terhadap masalah, serta menarik kesimpulan berdasarkan aturan-aturan yang telah dikuasai sebelumnya.

Pembelajaran dengan menggunakan model problem solving ini dapat dilakukan dengan jalan melatih peserta didik untuk menghadapi berbagai masalah baik masalah pribadi, masalah kelompok untuk dipecahkan sendiri atau bersama-sama. Menurut Hamalik (2005:151) "Proses pemecahan masalah memberikan kesempatan kepada peserta didik untuk berperan aktif dalam proses pembelajaran, mencari dan menemukan sendiri informasi data untuk diolah menjadi konsep, prinsip, teori, ataupun kesimpulan". Sedangkan Wina (2008:214) menjelaskan "Problem solving tidak mengharapkan peserta didik hanya sekedar mendengarkan, mencatat, kemudian menghafal materi pelajaran akan tetapi melalui model problem solving peserta didik aktif berfikir, berkomunikasi, mencari dan mengolah data dan akhirnya menyimpulkannnya".

Dari berbagai uraian di atas dapat disimpulkan bahwa model problem solving merupakan model yang mendorong peserta didik untuk berfikir secara sistimatis, berani menghadapi masalah, sehingga peserta didik mampu untuk memecahkan atau menyelesaikan masalah dengan menggunakan aturan-aturan yang telah dikuasai peserta didik sebelumnya, baik dalam kehidupan pribadi maupun kelompok. Proses pemecahan masalah ini membutuhkan mental dan intelektual dalam menemukan dan memecahkan masalah tersebut berdasarkan informasi yang akurat sehingga dapat di ambil suatu kesimpulan yang cermat.

Pembelajaran dengan Model problem solving mengarahkan peserta didik untuk memahami dan memiliki keterampilan pemecahan masalah. Maka berikut ini langkah-langkah Meodel problem solving menurut Polya (1973) yaitu (1) understand the problem; (2) devise a plan; (3) carry out the plan; (4) look back dalam bahasa Indonesianya (1) memahami masalah; (2) menyusun rencana; (3) melaksanakan rencana; (4) lihat kembali.

\section{METODE}

Jenis penelitian ini adalah penelitian tindakan kelas (PTK) dengan mengikuti empat tahapan yaitu perencanaan, pelaksanaan, observasi, dan refleksi. Penelitian ini dilaksanakan di SDN 146/X Tanjung Solok pada semester ganjil tahun ajaran 2021/2022 dengan subjek peserta didik kelas VI yang berjumlah sebanyak 17 orang peserta didik. Penelitian ini terdiri dari dua siklus, dimana masingmasing siklus terdiri dari dua kali pertemuan. Teknik pengumpulan data menggunakan lembar observasi, tes, catatan lapangan, dan dokumentasi. Data dianalisis dengan menggunakan persentase dan reduksi data terhadap kemampuan berfikir kritis siswa. 


\section{HASIL DAN DISKUSI}

\section{Hasil Penelitian}

Siklus I

\section{Perencanaan}

Pada tahap ini dipersiapkan segala sesuatu yang dibutuhkan pada awal pelaksanaan penelitian diantaranya: 1) Membuat Rancangan Pelaksanaan Pembelajaran (RPP) sesuai dengan model problem solving yang akan dilaksanakan, 2) Menyiapkan media pembelajaran yang sesuai dengan materi pertemuan, 3) Menyiapkan LKS yang mengacu kepada standar kompetensi, kompetensi dasar, serta tujuan pembelajaran yang dilakukan terhadap materi pembelajaran, alokasi waktu dan indikator pembelajaran, 4) Merancang instrumen, maksudnya membuat format lembaran berisi kualitas problem solving yang akan diamati selama kegiatan pembelajaran dikelompok, menyiapkan lembaran untuk catatan lapangan, menyiapkan lembaran observasi lapangan, 5) Merancang dan menyiapkan kelompok kooperatif yang dilakukan pada saat proses pembelajaran belum berlangsung. Jumlah peserta didik tiap kelompok pada penelitian adalah 4 orang dengan kelompok yang heterogen, 6) Merancang kuis yang akan diberikan setiap akhir pertemuan, selanjutnya diadakan penilaian. Penilaian berupa perhitungan skor perkembangan individu dan skor kelompok, 7) Mendiskusikan rencana yang telah disusun dengan observer, hal ini dilakukan sebagai evaluasi kegiatan rancangan, 8) Menyiapkan lembaran observasi untuk guru dan siswa.

\section{Pelaksanaan}

Pada pertemuan pertama siklus I dilaksanakan pada hari Kamis tanggal 16 September 2021 pukul 09.30 s.d 10.05 WIB dengan jumlah peserta didik 17 orang. Materi yang dibahas pada pertemuan pertama siklus I ini adalah "operasi Hitung Campuran Bilangan Cacah". Tujuan pembelajaran pada siklus I pertemuan pertama ini adalah " setelah mengikuti kegiatan pembelajaran problem solving dapat menumbuhkan sikap menyadari kebeesaran tuhan, sikap gotong royong, jujur, dan berani mengemukakan pendapat sehingga peserta didik dapat menyelesaikan masalah yang berkaitan dengan operasi hitung campuran dalam kehidupan sehari-hari.Pertemuan pertama ini diawali dengan kegiatan pendahuluan, kegiatan inti dan kegiatan akhir.

Dalam melaksanakan kegiatan pembelajaran, guru yang bertindak sebagai peneliti berusaha menerapkan kegiatan pembelajaran yang telah disusun dalam rencana pelaksanaan pembelajaran (RPP). Adapun materi yang disampaikan pada siklus I adalah operasi hitung campuran bilangan cacah. Guru membimbing peserta didik dengan pendekatan pemecahan masalah yaitu bagaimana peserta didik berfikir cara menyelesaikan masalah dengan menggunakan 4 (empat) tahap pemecahan masalah yaitu menganalisis, merencanakan, melakukan perhitungan, dan mengevaluasi jawaban. Pada saat guru dan peserta didik melakukan kegiatan pembelajaran, observer atau kolaborator melakukan pengamatan terhadap aktivitas guru dan peserta didik di kelas. Dengan menggunakan lembar observasi, observer mengamati aktivitas peserta didik dan guru berdasarkan aktivitas-aktivitas yang 
tampak dan berdasarkan kriteria penilaian yang telah ditetapkan serta memberikan catatan tambahan mengenai peroses pembelajaran berlangsung.

Pertemuan kedua dilaksanakan pada hari Kamis tanggal 23 September 2021 pada jam 09.30 s/d 10.05 WIB di ruangan kelas VI SDN 146/X Tanjung Solok dengan materi kelanjutan dari pertemuan pertama siklus I yaitu tentang operasi hitung campuran bilangan cacah. Pada pertemuan kedua ini dilakukan sebagai upaya untuk memperbaiki proses pembelajaran yang belum maksimal pada pertemuan pertama. Pertemuan kedua ini kembali diawali dengan kegiatan pendahuluan, kegiatan inti dan kegiatan akhir.

Pada kegiatan inti peserta didik diberi stimulus atau rangsangan untuk memuaskan perhatian pada materi operasi hitung campuran biangan cacah. Peserta didik bersera kelompoknya melakukan pengamatan dari permasalahan yang ada di buku paket berkaitan dengan materi operasi hitung bilangan cacah. Guru memberikan kesempatan kepada peserta didik untuk mengidentifikasi aneka pertanyaan yang berkaitan dengan tayangan yang disajikan dan dijawab melalui kegiatan pembelajaran tentang operasi hitung campuran bilangan cacah. Peserta didik dibentuk dalam beberapa kelompok untuk mendiskusikan, mengumpulkan informasi, mempresentasikan ulang, dan saling bertukar informasi mengenai operasi hitung campuran bilangan cacah. Peserta didik diarahkan untuk mengumpulkan dan mengeksplorasi data dari aneka sumber yang akan digunakan untuk menyelesaikan permasalahan di lembar kerja peserta didik (LKPD).

\section{Observasi}

Tahap observasi dilakukan bersamaan dengan pelaksanaan tindakan.Pada tahap ini peneliti dibantu oleh seorang observer, sedangkan yang bernama Neni Rosnita, S,Pd. SD yang merupakan kepala SDN 146/X Tanjung Solok. Hasil pengamatan terhadap kemampuan berfikir kritis siwa dalam pembelajaran matematika diambil dari hasil tes dapat dilihat dari tabel berikut ini:

Tabel 1. Kemampuan Berfikir Kritis Peserta Didik Siklus I

\begin{tabular}{|c|l|c|}
\hline No & \multicolumn{1}{|c|}{ Keterangan } & Nilai \\
\hline 1 & Jumlah & 880 \\
\hline 2 & Rata-Rata & 51.76 \\
\hline 3 & Peserta didik yang Tuntas & 7 \\
\hline 4 & Persentase Ketuntasan & 41 \\
\hline
\end{tabular}

Berdasarkan tabel di atas dapat disimpulkan bahwa kemampuan berfikir kritis peserta didik pada siklus I dilihat dari hasi tes masih berada di bawah kriteria ketuntasan yang ditetatpkan. Peserta didik yang tuntas sebanyak 7 orang atau $41 \%$ dari jumlah keseluruhan peserta didik sebanyak 17 orang. Hal ini berarti peserta didik yang mecapai nilai di atas KKM (60) hanya 7 orang, sedangnkan 10 orang lagi masih berada di bawah KKM. Untuk itu perlu adanya perbaikan-perbaikan pada siklus selanjutnya agar hasil kemampuan berfikir kritis peserta didik dapat meningkat dan mencapai kriteria ketuntasan belajar yang ditetapkan. 


\section{Refleksi}

Tahap refleksi siklus I dilaksanakan pada hari Sabtu Tanggal 10 s.d 1425 September 2021 dengan dibantu oleh seorang observer yang bernama Neni Rosnita, S.Pd. SD dan bertempat di ruangan kepala SDN 146/X Tanjung Solok. Pembelajaran pada siklus pertama telah dapat dilakukan sebagaimana yang telah direncanakan. Terutama menyangkut aktivitas belajar siswa. Pada umumnya peserta didik merasa termotivasi meskipun belum maksimal terutama penyangkut ketekunan dalam belajar. Pada siklus pertama dari beberapa kegiatan peserta didik telah mengikuti pembelajaran dengan baik kecuali pada keberanian, disebabkan karena peserta didik belum memiliki keberanian dalam mengeluarkan pendapat mereka. Peserta didik merasa tidak percaya diri karena takut salah jika mereka mengeluarkan pendapat dan akan ditertawakan oleh teman-temannya. Selain itu pada kegiatan diskusi yang juga tidak maksimal, hal ini disebabkan peserta didik belum memiliki pemahaman dalam penguasaan materi sehinga mereka melakukan kegiatan diskusi tidak bersemangat dan tidak serius dalam kelompok.

Melihat dari hasil yang ditemukan maka peneliti perlu memperbaiki tentang ketepatan peserta didik masuk kedalam kelas dengan menyampaikan kepada peserta didik supaya tidak terlambat lagi pada pertemuan selanjutnya. Guru harus menambah dalam pemberian kata-kata pujiandan memberikan reward kepada siswa, supaya peserta didik termotivasi kembali untuk menyimak materi yang disampaikan guru dengan sungguh. Adapun bentuk pujian yang diberikan kepada peserta didik yang berpartisipasi aktif dalam diskusi kelompok dengan kata bagus sekali karena telah aktif dalam diskusi kelompok.

Bagi laporan yang baik maka disamping pemberian nilai dituliskan kata-kata bagus. Pemberian bonus hadiah nilai tambahan bagi peserta didik yang mengumpulkan tepat waktu. Sedangkan bagi laporan yang belum sempurna dituliskan kata-kata mohon lebih giat lagi membaca. Untuk meningkatkan aktivitas belajar peserta didik guru harus membuat catatan kecil di papan tulis agar peserta didik memiliki sendiri catatan dan tidak menyalin catatan teman lain. Sehingga diharapkan apabila peserta didik telah mencatat sendiri catatannya mereka akan memiliki pemahaman akan materi dan mampu serta berani dalam mengemukakan pendapat dalam berdiskusi.

\section{Siklus II}

\section{Perencanaan}

Pada siklus II ini perencanaan dilakukan dua kali pertemuan yaitu : 1) Menyiapkan rencana pelaksanaan pembelajaran, 2) Menyiapkan media pembelajaran, 3) Menyiapkan lembar kerja siswa, 4) Menyiapkan daftar nama kelompok, 5) Menyiapkan lembar pengamatan diskusi, 6) Menyiapkan lembar evaluasi, 7) Menyiapkan lembar observasi pembelajaran di kelas.

\section{Pelaksanaan}

Pertemuan pertama siklus II dilaksanakn pada hari Kamis tanggal 4 Oktober 2021 pada jam $09.30 \mathrm{~s} / \mathrm{d}$ 10.05 WIB bertempat di ruangan kelas VI SDN 146/X tanjung Solok dengan membahas materi tentang "Operasi Hitung Campuran Bilangan Pecahan dan desimal". Tujuan pembelajaran 
pada pertemuan pertama siklus II ini adalah setelah mengikuti pembelajaran peserta didik dapat melakukan operasi hitung campuran yang melibatkan bilangan cacah pecahan, dan decimal. Pertemuan pertama siklus II dilaksanakan melalui tiga tahapan kegiatan yaitu kegiatan pendahuluan, kegiatan inti, dan kegiatan penutup.

Pada kegiatan inti ini peserta didik diberi stimulus atau rangsanagan untuk memusatkan perhatian pada materi operasi hitung campuran bilangan pecahan dan decimal. Peserta didik bersama kelompoknya melakukan pengamatan dari permsalahan yang ada di buku paket berkaitan dengan materi. Guru memberikan kesempatan pada peserta didik untuk mengidentifikasi aneka pertanyaan yang berkaitan dengan tayangan yang disajikan dan dijawab melalui kegiatan pembelajaran tentang operasi hitung campuran bilangan pecahan dan decimal. Peserta didik duduk dalam kelompok untuk mendiskusikan, mengumpulkan informasi, mempresentasikan ulang, dan saling bertukar informasi mengenai operasi hitung campuran bilangan pecahan dan decimal dan kemudain diarahkan untuk melaksanakan dan meyelesaikan permasalahan yang ada di LKPD.

Pertemuan kedua merupakan upaya untuk lebih memaksimalkan peningkatan proses pembelajaran agar kemampuan kemampuan berfikir kritis peserta didik lebih meningkat dari KKM yang ditentukan. Pertemuan kedua dilaksanakan pada hari Rabu tanggal 11 Oktober 2021 pada jam 09.30 s.d 10.05 WIB dengan jumlah peserta didik 17 orang. Pertemuan kedua siklus II membahas materi kelanjutan dari pertemuan pertama siklus II. Pertemuan kedua diawali dengan kegiatan pendahuluan, kegiatan inti dan kegiatan akhir. Tahap pelaksanaan terdiri dari tiga kegiatan yaitu kegiatan penutup, kegiatan inti dan kegiatan penutup.

Kegiatan perencanaan yang dilakukan pada siklus II sama dengan perencanaan pada siklus I sebelumnya. Berdasarkan hasil refleksi tahap perencanaan ini akan membahas bagaimana pemecahan masalah yang ada pada siklus I, adapun kelemahan yang ditemukan selama siklus I diminimalisir. Dari refleksi pada siklus I, guru mempersiapkan tindakan yang akan dilaksanakan pada siklus II. Dari kelemahan siklus I yang telah siuraikan pada refleksi siklus I maka guru berupaya untuk meningkatkan motivasi belajar, guru akan memberikan memberikan pujian dan reward kepada siswa, supaya peserta didik termotivasi kembali untuk menyimak materi yang disampaikan guru dengan sungguh.

Bagi peserta didik yang menyiapkan tepat waktu project mereka, akan diberikan bonus hadiah nilai tambahan peserta didik mengumpulkan tepat waktu. Bagi peserta didik yang terlambat guru akan memberikan sanksi seperi menghapus papan tulis atau merapikan meja teman-teman yang belum rapi sebelum pembelajaran dilaksanakan. Guru juga memberikan penguatan, memotivasi peserta didik dan arahan agar peserta didik lebih aktif lagi selama proses pembelajaran berlangsung.

\section{Observasi}

Tahap observasi dilakukan bersamaan dengan pelaksanaan tindakan. Pada tahap ini peneliti dibantu oleh seorang observer, sedangkan yang bernama Neni Rosnita, S,Pd. SD yang merupakan 
kepala SDN 146/X Tanjung Solok. Hasil pengamatan terhadap kemampuan berfikir kritis siwa dalam pembelajaran matematika diambil dari hasil tes dapat dilihat dari tabel berikut ini:

Tabel 2. Kemampuan Berfikir Kritis Peserta Didik Siklus II

\begin{tabular}{|c|l|c|}
\hline No & \multicolumn{1}{|c|}{ Keterangan } & Nilai \\
\hline 1 & Jumlah & 1270 \\
\hline 2 & Rata-Rata & 74.71 \\
\hline 3 & Peserta didik yang Tuntas & 14 \\
\hline 4 & Persentase Ketuntasan & 82 \\
\hline
\end{tabular}

Berdasarkan tabel di atas dapat disimpulkan bahwa kemampuan berfikir kritis peserta didik pada siklus II dilihat dari hasi tes sudah berada di atas kriteria ketuntasan yang ditetatpkan. Peserta didik yang tuntas sebanyak 14 orang atau $82 \%$ dari jumlah keseluruhan peserta didik sebanyak 17 orang. Hal ini berarti peserta didik yang mencapai nilai di atas KKM (60) sebanyak14 orang, sedangnkan 3 orang lagi masih berada di bawah KKM. Hal ini berarti kriteria ketuntasan belajar yang diharapkan sudah tercapai. Untuk itu tetap perlu adanya perbaikan-perbaikan pada siklus selanjutnya agar hasil kemampuan berfikir kritis peserta didik dapat meningkat dan menjadi lebih baik lagi.

\section{Refleksi}

Tahap refleksi siklus II dilaksanakn pada hari Jumat tanggal 13 Oktober 2021 bertempat di ruangan kepala SDN 146/X Tanjung Solok yang dibantu oleh seorang observer yang bernama Neni Rosnita, S.Pd. SD. Berdasarkan hasil pengamatan (observasi) peneliti dengan observer dapat didiskripsikan bahwa pelaksanaan pembelajaran Matematika dengan menggunakan model Problem Solving pada siklus II dapat meningkatkan aktivitas dan hasil belajar siswa, walaupun dalam kategori baik. Hal ini menandakan bahwa masih ada peserta didik yang belum mencapai aktivitas maksimal seperti: 1) Aktivitas peserta didik dalam merencanakan tugas yang akan dipelajari, 2) Aktivitas peserta didik dalam melaksanakan investigasi, 3) Aktivitas peserta didik dalam mempresentasikan laporan akhir. Sedangkan untuk hasil belajar peserta didik masih mencapai kategori baik, namun sudah mencapai KKM. Hal ini disebabkan: 1) Guru masih mendominasi pembelajaran, 2) Masih ada peserta didik yang kurang mengerti tentang materi pembelajaran, 3) Peserta didik dalam melakukan investigasi kurang kerjasama dan berbagi, 4) Kurang menghargai pendapat teman, 5) Kurang berani mengemukakan pendapat.

Berdasarkan refleksi tersebut, diharapkan kepada guru kelas VI SDN 146/X Tanjung Solok dapat menerapkan model ini dalam proses pembelajaran agar hasil yang dicapai lebih maksimal. Peneliti mengakhiri penelitian ini dengan perolehan hasil hanya baik. Karena hasil yang diperoleh sudah melebihi Kriteria Ketuntasan Minimal yaitu 75.

\section{Diskusi}

Saat mengikuti setiap aktivitas pembelajaran peserta didik berusaha untuk memahami materi yang diajarkan melalui mendengarkan penjelasan guru dan mengerjakan latihan yang diberikan guru, 
serta mengikuti langkah-langkah problem solving dengan materi yang dipelajari. Hal ini menunjukkan bahwa peserta didik sangat tertarik dan senang dengan metode yang diterapkan. Penerapan metode problem solving diperoleh beberapa temuan, bahwa dapat meningkatkan kemampuan berfikir kritis peserta didik dan proses pembelajaran lebih menarik dan peserta didik lebih antusias mengikuti pembelajaran. Keberhasilan aktivitas peserta didik ini terihat dari adanya perubahan sikap dan tingkah laku peserta didik serta pemikiran peserta didik selama proses pembelajaran berlangsung. Penjelasan ini sejalan dengan pendapat yang disampaikan oleh Rosalia (2005:4) keaktivan peserta didik selama pembelajaran berlangsung merupakan salah satu adanya keberhasilan, keinginan dan motivasi dari peserta didik untuk belajar, dimana seorang peserta didik dikatakan aktif apabila peserta didik memiliki ciri-ciri diantaranya aktif bertanya kepada guru, atau kepada peserta didik lainnya, mau mengerjakan tugas yang diberikan guru, mampu menjawab setiap pertanyaan, senang diberi tugas belajar.

\section{KESIMPULAN}

Berdasarkan hasil penelitian dan pembahasan dapat disimpulkan bahwa melalui model pembelajaran problem solving dapat meningkatkan kemampuan berfikir kritis peserta didik dalam pembelajaran matematika di kelas VI SDN 146/X Tanjung Solok. Hal ini dapat dilihat dari persentase ketuntasan belajar peserta didik dari siklus I (41\%) dan meningkat pada siklus II (82\%).

Berdasarkan kesimpulan di atas maka peneliti menyarankan sebagai berikut: 1) Hendaknya guru kreatif dan selalu berinovasi dalam pembelajaran, dengan memanfaatkan media dan model pembelajaran dalam rangka meningkatkan hasil belajar siswa, 2) Hasil penelitian ini dapat diterapkan di kelas-kelas lain maupun di sekolah lain. Tentu dengan penyesuaian dan modifikasi seperlunya sesuai dengan konteks kelas atupun sekolah masing-masing.

\section{REFERENSI}

Abdul,Majid. (2009). Perencanaan Pembelajaran. Bandung: PT Remaja Rosda.

Abin Syamsuddin Makmun. (2007). Psikologi Kependidikan. Bandung: PT. Remaja Rosdakarya

Ali Hamzah dan Muhlisrarini. (2014). Perencanaan dan Strategi Pembelajaran. Matematika.

Jakarta: Raja Grafindo Persada.

Ambarita, Alben. (2006). Manajemen Pembelajaran. Jakarta: Departemen. Pendidikan Nasional.

Anna Poedjiadi. (2005). Sains Teknologi Masyarakat. Bandung. PT Remaja. Rosdakarya

Badan Standar Nasional Pendidikan. (2006). Panduan Penyusunan Kurikulum Tingkat Satuan Pendidikan Jenjang Pendidikan Dasar dan Menengah. Jakarta: BSNP

Depdiknas .2003. Undang-undang RI No.20 tahun 2003.tentang sistem pendidikan nasional.

Depdiknas. (2007). Kurikulum Tingkat Satuan Pendidikan (KTSP). Jakarta: Depdiknas

Hamalik, Oemar. (2005). Perencanaan Pengajaran Berdasarkan Pendekatan. Sistem. Jakarta: PT Bumi Aksara. 
Peningkatan Kemampuan Berfikir Kritis Peserta Didik pada Muatan Matematika Melalui Model Pembelajaran Problem Solving di Kelas VI SDN 146/X Tanjung Solok pada Semester Ganjil Tahun Ajaran 2021/2022, Toni

Hudojo. (1998). Mengajar Belajar Matematika. Jakarta: Depdikbud.

Muhibbin Syah. 2007.Psikologi Pendidikan Dengan Pendekatan Baru. Bandung: PT Remaja Rosdakarya.

Nasution. (2003). Metode Penelitian Naturalistik Kualitatif. Bandung: Tarsito.

Nuryani. (2005). Strategi Belajar Mengajar Biologi. Malang: IKIP Malang Press.

Permendiknas No 22 Tahun 2006 Tentang Standar Isi. Jakarta : Depdiknas

Polya, George. (1973). How to Solve It: A New Aspect of Mathematical Method. (Second Edition). New Jersey: Princeton University Press.

Soedjadi. (2000). Kiat Pendidikan Matematika di Indonesia. Jakarta: Direktorat

Suriasumantri, Jujun S. 2005. Filsafat Ilmu; Sebuah Pengantar Populer. Jakarta: Pustaka Sinar Harapan

Yulnaida. 2015 Peningkatan Kemampuan Berpikir Kritis dengan Metode Pemecahan Masalah Peserta didik Kelas III.A MIN Gunuang Sarik Kota Padang

Gunawan, Adi W.2003. Genius Learning Strategy Petunjuk Praktis Untuk Menerapkan Accelerated Learning. Jakarta. Gramedia Pustaka Utama

Krulik, Stephen and Rudnik, Jesse A. 1998. The New Sourcebook for Teaching Reasoning and Problem Solving in Elemntary School. Amerika: Ally dan Bacon

Susanto, Ahmad. (2013). Teori Belajar dan Pembelajaran di Sekolah Dasar. Jakarta: Prenada Media Group

Suherman, Erman dkk. (2003). Strategi Pembelajaran Matematika Kontemporer. Bandung: PT Remaja Rosdakarya.

Van de Walle, John A. (2008). Matematika Sekolah Dasar dan Menengah Jilid I Pengembangan Pengajaran. Jakarta : Erlangga

Wahyudin. (2008). Pembelajaran dan Model-model Pembelajaran. Jakarta: IPA Abong

Winna, Sanjaya. (2008). Strategi Pembelajaran Berorientasi Standar Proses Pendidikan. Jakarta: Kencana Prenada Media Grouf.

Yamin, Martinis. (2009). Desain Pembelajaran Berbasis Tingkat Satuan Pendidikan. Jakarta: Gaung Persada Press. 